\title{
Pengaruh Puguntano terhadap HOMA-IR Pada Pasien Diabetes Melitus yang Baru Didiagnosis
}

\author{
Billy Stinggo Siahaan, Dharma Lindarto \\ Divisi Endokrin dan Metabolik Departemen Ilmu Penyakit Dalam \\ Fakultas Kedokteran Universitas Sumatera Utara Medan/RSUP H. Adam Malik Medan
}

\begin{abstract}
Abstrak
Resistensi insulin sangat penting pada diabetes melitus sebagai prediktor yang kuat terhadap perkembangan diabetes melitus dan target terapi saat hiperglikemia sudah terjadi. HOMA-IR merupakan suatu metode yang telah tervalidasi dalam menilai resistensi insulin pada pasien diabetes melitus. Puguntano suatu tanaman budidaya yang terdapat di Sumatra Utara diketahui memiliki efek antidiabetes. Sampel diambil dari tahun 20152016 di Rumah Sakit Haji Adam Malik Medan. Studi ini mencoba menilai pengaruh puguntano sebagai tanaman budidaya di Sumatera Utara terhadap resistensi insulin pada pasien Diabetes Melitus tipe 2. Untuk mengetahui pengaruh pemberian serbuk puguntano terhadap HOMA-IR pada pasien DM tipe 2 yang baru didiagnosis. Dilakukan uji klinis terbuka dengan desain paralel selama 12 minggu pada 24 pasien (12 pasien dan 12 kontrol) Diabetes Mellitus tipe 2 yang baru terdiagnosa yang dibagi dalam 2 grup masing-masing diberikan puguntano dan metformin selama 12 minggu. HOMA-IR dan HbA1c diperiksa pada awal dan akhir pengobatan (minggu ke 12). Didapatkan penurunan HOMA-IR rata-rata pada grup puguntano $1,71( \pm 2,29)(p=0,034)$. Tidak didapatkan perbedaan penurunan HOMA-IR rata-rata antara kedua grup puguntano vs metformin $1.71( \pm 2,29)$ vs 0,80 $( \pm 1,47)(p=0,402)$. Didapatkan penurunan nilai HOMA-IR dengan pemberian puguntano pada penderita Diabetes Mellitus tipe 2 yang baru didiagnosis. Simpulan, efek puguntano dalam mengontrol gula darah terutama dalam perannya memperbaiki sensitifitas insulin tidak jauh berbeda dengan metformin yang telah menjadi obat standar dalam pengobatan lini pertama diabetes melitus tipe 2. [MKB. 2017;49(2):67-72]
\end{abstract}

Kata kunci: Diabetes melitus, HOMA-IR, puguntano

\section{Effect of Puguntano on HOMA-IR in Newly Diagnosed Type 2 Diabetes Mellitus}

\begin{abstract}
Insulin resistance is important not only as a powerful predictor of future development of type 2 diabetes mellitus but also as a therapeutic target once hyperglycemia is present. HOMA-IR is a method for assessing insulin resistance that has been validated worldwide. Puguntano is one of the traditional plants found in North Sumatera that has been recognized for its anti-diabetic effect. Samples were taken from 2015-2016 at H. Adam Malik General Hospital Medan. This study tried to assess the effect of puguntano as a traditional plant in North Sumatera on insulin resistance in type 2 diabetes melitus patients and aimed to determine the effect of puguntano treatment on HOMA-IR in newly diagnosed type 2 diabetes mellitus patients. This was a randomized open clinical trial on 24 newly diagnosed type 2 diabetes mellitus patients (12 patients and 12 controls) divided into 2 groups who were assigned to receive puguntano or Metformin for 12 weeks. HOMA-IR and Hba1c were determined at baseline and at the end of 12 weeks. In puguntano group, the mean decrease of HOMA-IR was $1.71( \pm 2.29)(p=0.034)$. There was no difference in terms of the mean decrease of HOMA-IR between the puguntano and Metformin group, which was $1.71( \pm 2.29)$ vs $0.80( \pm 1.47)(\mathrm{p}=0.402)$. There was a decrease mean of HOMA-IR level with puguntano treatment in newly diagnosed type 2 diabetes mellitus patients which was statistically significant. In conclusions, the effect of puguntano in controlling blood sugar especially in its role of improving insulin sensitivity is not much different from metformin which has become a standard drug in the first-line treatment of type 2 diabetes mellitus. [MKB. 2017;49(2):67-72]
\end{abstract}

Key words: Diabetes mellitus, HOMA-IR, puguntano

Korespondensi: Billy Stinggo P. Siahaan, dr., Sp PD., Divisi Endokrin dan Metabolik Departemen Ilmu Penyakit Dalam Fakultas Kedokteran Universitas Sumatera Utara/RSUP. H. Adam Malik Medan, E-mail: billystinggo@gmail.com 


\section{Pendahuluan}

Dua penyebab utama hiperglikemia pada DM tipe 2 adalah gangguan pada sekresi insulin dan peningkatan resistensi insulin. ${ }^{1}$ Insulin resisten sangat penting pada diabetes melitus tidak hanya sebagai prediktor yang kuat terhadap perkembangan diabetes melitus, tetapi juga sebagai target terapi saat hiperglikemia sudah terjadi. $^{2}$

Pemanfaatan obat-obat tradisional kini terus meningkat dan berkembang dengan pesat di masyarakat. Keadaan ini didukung oleh berbagai faktor serta isu yang berkembang saat ini berupa sikap kembali ke alam (back to nature). Pemanfaatan dari obat tradisional di berbagai daerah merupakan warisan turun temurun berdasar atas pengalaman/empirik, selanjutnya berkembang melalui pembuktian ilmiah melalui uji pra-klinik dan uji klinik. Puguntano [Curanga fel-terrae (Lour.) Merr.] atau sering disebut picria fel-terrae merupakan tanaman dari famili Scrophulariaceae yang tumbuh di wilayah Asia seperti Cina, India, Indonesia, Filipina, Malaysia dan Myanmar. Di Indonesia, tanaman ini tersebar di daerah Sumatera, Jawa, Kalimantan, dan Maluku. ${ }^{3}$

Studi terdahulu telah berhasil mengisolasi $\beta$-sisterol pada tanaman puguntano merupakan kandungan yang diyakini sebagai salah satu efek antidiabetes dari tanaman ini dan pemberian ekstrak ini pada mencit selama sepuluh hari menurunkan kadar gula darah sebesar 44,47\%. ${ }^{4}$ Penelitian ini mencoba melihat efek puguntano terhadap resistensi insulin pada pasien DM tipe 2 yang baru didiagnosis.

\section{Metode}

Penelitian dilakukan secara uji klinis dengan metode desain paralel tidak berpasangan dengan kelompok perlakuan dan kelompok kontrol secara independen serta randomisasi dengan cara simple random sampling. Sampel diambil dari tahun 2015-2016 di Rumah Sakit Haji Adam Malik Medan. Kriteria inklusi yaitu pasien DM tipe 2 yang baru didiagnosis dengan usia $>17$ tahun dan bersedia mengikuti penelitian. Kriteria eksklusi diantaranya pasien DM tipe 1, anemia (laki-laki $\mathrm{Hb}<12 \mathrm{~g} / \mathrm{dL}$ dan wanita $\mathrm{Hb}$ $<11 \mathrm{~g} / \mathrm{dL}$ ), hipertensi, gangguan fungsi ginjal dan hati, serta tidak menyelesaikan pengobatan sesuai dengan prosedur (drop out). Didapatkan 24 pasien DM tipe 2 yang baru didiagnosis yang telah memenuhi kriteria inklusi penelitian yang kemudian dibagi menjadi 2 grup. Grup pertama (12 orang) diberikan terapi standar menggunakan metformin yang dimulai dari dosis 1x500 mg dan dititrasi dengan dosis maksimal harian 3x500 mg sampai tercapai target terapi. Grup kedua diberikan ekstrak puguntano yang dikemas dalam bentuk kapsul yang sama baik bentuk dan warnanya dengan metformin. Dosis Puguntano yang diberikan dimulai dengan 1x200 mg dan dititrasi dengan dosis maksimal harian 2x200 mg sampai tercapai target terapi. Kedua grup dilakukan pengawasan secara ketat setiap minggunya dengan kunjungan ke rumah dan pemeriksaan gula darah mingguan. Setiap pasien juga diberikan nomor telepon yang dapat dihubungi apabila terjadi efek samping yang tidak diinginkan. Seluruh pasien pada kedua grup juga diberikan edukasi melalui seminar baik mengenai pola hidup dan diet pada awal penelitian. Kedua grup pada awal minggu pertama dilakukan pemeriksaan HOMA-IR dan diberikan intervensi selama 3 bulan dengan pengawasan ketat dan dilakukan pemeriksaan HOMA-IR di akhir penelitian.

Data-data epidemiologi subjek penelitian ditampilkan mempergunakan tabulasi untuk memperlihatkan gambaran deskriptif. Analisis komparasi data memakai analisis t-dependen untuk data yang berdistribusi normal dan juga Wilcoxon untuk data yang tidak berdistribusi normal. Untuk analisis komparasi grup studi dan kontrol digunakan analisis Mann Whitney. Data diolah dan dianalisis dengan batas kemaknaan $\mathrm{p}<0,05$. Ethical clearance dan informed consent. Ethical clearance tersebut telah diperoleh dari Komite Penelitian Bidang Kesehatan Fakultas Kedokteran Universitas Sumatera Utara dengan Nomor 306/KOMET/FK USU/2015..

\section{Hasil}

Penelitian ini diikuti oleh sebanyak 24 subjek DM tipe 2 yang telah memenuhi kriteria inklusi yang dibagi menjadi dua kelompok yang berjumlah 12 orang masing-masing dan tidak didapatkan perbedaan karakteristik dasar yang signifikan antar kedua grup (Tabel 1).

Hasil penelitian ini memperlihatkan bahwa pada subjek yang telah mendapat puguntano terdapat perbedaan rata-rata yang signifikan kadar gula darah puasa, HbA1c, serta HOMAIR antara sebelum dan sesudah pemberian puguntano $(p<0,05)$. Sementara itu, pada kelompok subjek yeng memperoleh metformin hanya parameter kadar gula darah puasa dan 
Tabel 1 Karakteristik Subjek Penelitian

\begin{tabular}{lccc}
\hline Karakteristik & Puguntano (n=12) & Metformin (n=12) & p \\
\hline Jenis Kelamin & & & \\
$\quad$ Laki-laki / & $3 / 12$ & $4 / 12$ & \\
$\quad$ Perempuan / & $9 / 12$ & $8 / 12$ & \\
Usia, rata-rata (SB), tahun & $55,3(4,38)$ & $52,5(5,52)$ & 0,177 \\
Antropometri & & & \\
Berat Badan, rata-rata (SB), kg & $62,17(9,97)$ & $61,63(7.73)$ & 0,594 \\
Tinggi Badan, rata-rata (SB), cm & $157,25(5,08)$ & $157,92(6.76)$ & 0,787 \\
IMT, rerata (SB), kg/m & $25,09(3,65)$ & $24,76(3.26)$ & 0,811 \\
Lingkar perut, rata-rata (SB), cm & $94,25(3,72)$ & $95(4.57)$ & 0,664 \\
Status glukosa & & & \\
$\quad$ Gula darah puasa, mg/dL & $223,17(118,81)$ & $169,17(67.16)$ & 0,299 \\
Gula darah 2 jam PP, mg/dL & $301,25(156,64)$ & $251,83(116,93)$ & 0,391 \\
Hba1c, \% & $9,66(3,28)$ & $8,93(1,87)$ & 0,356 \\
Insulin puasa, uIU/mL & $7,37(3,63)$ & $7,85(6,81)$ & 0,563 \\
HOMA-IR & $3,79(2,22)$ & $3,3(3,16)$ & 0,655 \\
\hline
\end{tabular}

*Signifikan

HbA1c yang menunjukkan perbedaan rata-rata yang signifikan antara sebelum dan sesudah pemberian metformin $(p<0,05)$.

Pada kelompok puguntano diketahui bahwa kadar HOMA-IR rata-rata sebelum pemberian intervensi adalah 3,79 sedangkan pada sesudah intervensi menunjukkan penurunan rata-rata menjadi 2,08. Hasil analisis mempergunakan uji Wilcoxon membuktikan bahwa terdapat perbedaan rata-rata yang signifikan untuk kadar HOMA-IR rata-rata antara sebelum dan sesudah intevensi $(p=0,034)$. Pada kelompok subjek yang menerima metformin, rata-rata kadar HOMA-IR sebelum intervensi adalah 3,3 dan sesudah intervensi menjadi 2,5. Hasil analisis menggunakan uji Mann Whitney membuktikan bahwa terdapat penurunan rata-rata HOMA-IR tetapi tidak bermakna secara statistik $(p=0,402)$.

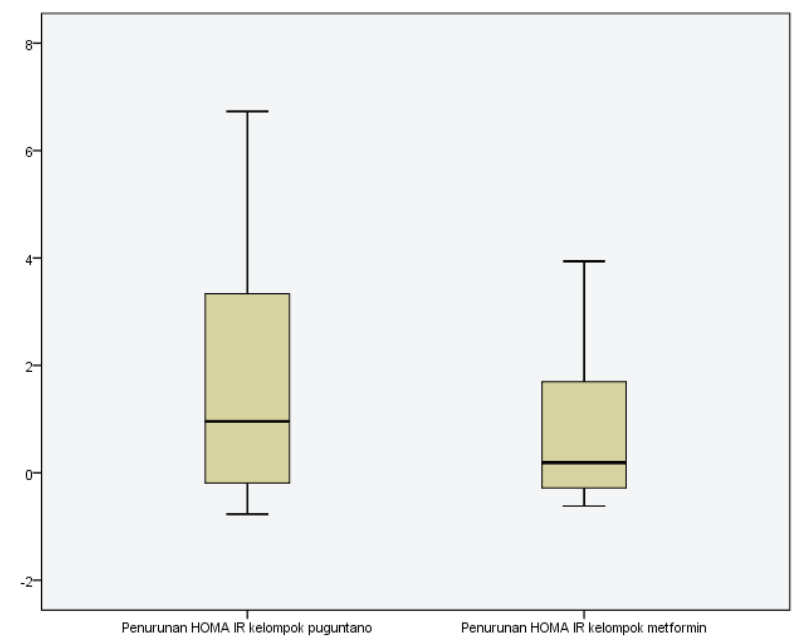

Gambar Grafik Boxplot Perbedaan Delta Penurunan Kadar HOMA-IR antara Kelompok Puguntano dan Metformin 
Tabel 2 Perbandingan Parameter Hba1c, Gula Darah Puasa, Gula Darah 2 Jam PP, Insulin Puasa, HOMA - IR antara Sebelum dan Sesudah Intervensi Puguntano dan Metformin Selama 12 Minggu

\begin{tabular}{|c|c|c|c|c|c|c|c|c|c|}
\hline \multirow[b]{2}{*}{ Variabel } & \multicolumn{3}{|c|}{ Puguntano } & \multirow[b]{2}{*}{$\mathbf{p}^{\mathbf{a}}$} & \multicolumn{3}{|c|}{ Metformin } & \multirow[b]{2}{*}{$\mathbf{p}^{\mathbf{b}}$} & \multirow[b]{2}{*}{$\mathbf{p}^{\mathrm{c}}$} \\
\hline & $\begin{array}{c}\text { Sebelum, } \\
\text { Rata-rata } \\
\text { (SB) }\end{array}$ & $\begin{array}{l}\text { Sesudah, } \\
\text { Rata- } \\
\text { rata (SB) }\end{array}$ & $\Delta$ & & $\begin{array}{c}\text { Sebelum, } \\
\text { Rata-rata } \\
\text { (SB) }\end{array}$ & $\begin{array}{c}\text { Sesudah, } \\
\text { Rata-rata } \\
\text { (SB) }\end{array}$ & $\Delta$ & & \\
\hline $\begin{array}{l}\text { Gula darah } \\
\text { puasa, mg / } \\
\text { dL }\end{array}$ & $\begin{array}{c}223,17 \\
(118,81)\end{array}$ & $\begin{array}{c}165,5 \\
(68,14)\end{array}$ & $\begin{array}{c}57,67 \\
(71,59)\end{array}$ & $0.012^{*}$ & $\begin{array}{l}169,17 \\
(67,16)\end{array}$ & $\begin{array}{c}127,5 \\
(60,69)\end{array}$ & $\begin{array}{c}41,67 \\
(39,59)\end{array}$ & $0,010^{*}$ & 0,773 \\
\hline $\begin{array}{l}\text { Gula darah } 2 \\
\text { jam PP, mg/ } \\
\text { dL }\end{array}$ & $\begin{array}{c}301,25 \\
(156,64)\end{array}$ & $\begin{array}{l}276,25 \\
(97,49)\end{array}$ & $\begin{array}{c}25 \\
(118,56)\end{array}$ & 0.480 & $\begin{array}{c}251,83 \\
(116,93)\end{array}$ & $\begin{array}{c}245 \\
(107,45)\end{array}$ & $\begin{array}{c}6,83 \\
(126,18)\end{array}$ & 0,875 & 0,862 \\
\hline Hba1c, \% & $\begin{array}{c}9,66 \\
(3,28)\end{array}$ & $\begin{array}{c}8.13 \\
(2.04)\end{array}$ & $\begin{array}{c}1,53 \\
(1,99)\end{array}$ & $0,022^{*}$ & $\begin{array}{c}8,93 \\
(1,87)\end{array}$ & $\begin{array}{c}7,44 \\
(2,73)\end{array}$ & $\begin{array}{l}1,48 \\
(2,0)\end{array}$ & $0,012^{*}$ & 0,686 \\
\hline $\begin{array}{l}\text { Insulin Puasa, } \\
\mathrm{uIU} / \mathrm{mL}\end{array}$ & $\begin{array}{c}7,37 \\
(3,63)\end{array}$ & $\begin{array}{c}5,4 \\
(2.97)\end{array}$ & $\begin{array}{c}1,97 \\
(3,88)\end{array}$ & 0,107 & $\begin{array}{c}7,85 \\
(6,81)\end{array}$ & $\begin{array}{c}7,55 \\
(6,42)\end{array}$ & $\begin{array}{c}0,30 \\
(2,22)\end{array}$ & 0,534 & 0,386 \\
\hline HOMA - IR & $\begin{array}{c}3,79 \\
(2,22)\end{array}$ & $\begin{array}{l}2,08 \\
(1,3)\end{array}$ & $\begin{array}{c}1,71 \\
(2,29)\end{array}$ & $0,034^{*}$ & $\begin{array}{c}3,3 \\
(3,16)\end{array}$ & $\begin{array}{c}2,5 \\
(2,35)\end{array}$ & $\begin{array}{c}0,80 \\
(1,47)\end{array}$ & 0,087 & 0,402 \\
\hline
\end{tabular}

$\mathrm{p}^{\mathrm{a}}$ : nilai p sebelum dan sesudah kelompok puguntano $\mathrm{p}^{\mathrm{b}}$ : nilai p sebelum dan sesudah kelompok metformin $\mathrm{p}^{\mathrm{c}}$ : nilai $\mathrm{p}$ delta antara kelompok puguntano dan metformin *signifikan, ${ }^{* *}$ sangat signifikan

Penurunan HOMA-IR kelompok puguntano menunjukkan sedikit lebih besar dibanding dengan kelompok metformin, yaitu dengan delta penurunan masing-masing adalah 1,71 dan 0,8, namun berdasar atas uji Mann-Whitney perbedaan delta pada penurunan kadar HOMAIR rata-rata diantara grup puguntano dan juga metformin tidak terdapat perbedaan rata-rata delta yang signfikan $(\mathrm{p}=0,402)$.

\section{Pembahasan}

Pemanfaatan obat tradisional terus meningkat dan berkembang dengan pesat di masyarakat. Hal ini didukung oleh berbagai faktor dan isu yang berkembang saat ini berupa sikap kembali ke alam (back to nature). Studi oleh Juwita ${ }^{5}$ melaporkan bahwa tanaman daun puguntano mempunyai potensi sebagai anti-inflamasi dalam bentuk ekstrak dan memiliki efek antidiabetes. Penelitian itu juga menemukan bahwa tumbuhan puguntano tersebut mengandung senyawa kimia golongan glikosida, flavonoid, tanin, dan steroid/ triterpenoid yang keseluruhan zat ini berperan meningkatkan sensitivitas insulin melalui insulin signaling-pathway. ${ }^{5}$

Perbaikan sensitivitas insulin pada pasien diabetes melitus tipe 2 dinilai mempergunakan penurunan kadar HOMA-IR pada kelompok puguntano setelah 12 minggu perlakuan dan penurunan ini bermakna secara statistik. Kadar HOMA-IR subjek pada kelompok puguntano sebelum pemberian intevensi adalah 3,79 dan sesudah intervensi turun menjadi 2,08 dan hasil analisis dengan uji Wilcoxon ditemukan perbedaan HOMA-IR rata-rata yang signifikan antara sebelum dan juga sesudah pemberian puguntano dengan rata-rata penurunan 1,71 $( \pm 2,09)(p=0,034)$.

Hasil ini juga sejalan dengan penelitian Saha dkk. ${ }^{6}$ yang menyatakan bahwa Terpenoid sebagai salah satu zat yang diobservasi pada tanaman ini juga telah diinvestigasi memiliki efek antidiabetik. Zat ini melalui uji klinis memiliki efek pleotropik seperti transaktivasi AMPactivated kinase sehingga dapat memperbaiki sensitivitas insulin. ${ }^{6}$

Memang sejauh ini penulis tidak menemukan penelitian terdahulu yang telah membandingkan 
secara langsung kadar HOMA-IR terhadap pemberian puguntano pada manusia. Namun, beberapa penelitian yang tidak jauh berbeda dengan yang telah dilakukan. Studi oleh Sitorus $\mathrm{dkk}^{4}$ mendapatkan ekstrak $n$-hexane dari daun picria fel-terrae lour memiliki kemampuan menurunkan nilai glukosa darah dan reduksi selama 10 hari sebesar $44.47 \%$ pada mencit. Penelitian ini juga sejalan dengan penelitian sebelumnya pada manusia oleh Harfina dkk. ${ }^{3}$ yang menyatakan bahwa observasi klinis serbuk simplisia daun puguntano mempunyai efek menurunkan kadar gula darah pada pasien diabetes melitus dengan dosis $2 \mathrm{~g}$, 3 kali sehari selama 14 hari yang diberikan secara oral dalam bentuk seduhan.

Penelitian ini mampu membuktikan bahwa obat puguntano memiliki efek anti diabetes terutama melalui kerjanya dalam memperbaiki sensitivitas insulin pada pasien diabetes melitus tipe 2 .

Metformin merupakan salah satu jenis obat hipoglikemik oral yang mempunyai efek utama untuk mengurangi produksi glukosa hati (glukoneogenesis) di samping juga memperbaiki ambilan glukosa perifer. Efikasi, keamanan, serta efek menguntungkan dari segi kardiovaskular dan metabolik membuat obat ini menjadi agen pilihan pertama dalam beberapa tahun terakhir untuk menurunkan glukosa pada pengobatan pasien diabetes melitus tipe $2 .{ }^{7}$

Beberapa penelitian lain telah mencoba menghubungkan efek metformin tersebut dalam menurunkan resistensi insulin. Penelitan oleh Iliadis dkk. ${ }^{8}$ di Yunani pada 41 pasien diabetes melitus yang baru terdiagnosis yang diberikan metformin dengan dosis titrasi (maksimal $1.700 \mathrm{mg} /$ hari) dan diet selama $18 \mathrm{minggu}$ mendapatkan penurunan HOMA-IR rata-rata yang signifikan, yaitu 4,01 $( \pm 4,67)$ dengan $p$ value $<0,01$.

Hasil penelitian yang tidak jauh berbeda juga didapatkan oleh Ma dkk. (2014) di China yang mengobservasi pemberian metformin sebagai monoterapi pada 54 pasien Diabetes melitus yang baru terdiagnosis. Pemberian metformin selama 3 bulan memberikan hasil penurunan HOMA-IR dari 3,92 $( \pm 0,38)$ menjadi $2,58( \pm 0,22)$ dengan $\mathrm{p}<0.01 .^{9}$ Penelitian oleh Krysiak dkk. ${ }^{10}$ di Polandia pada 19 pasien dengan toleransi glukosa terganggu menemukan terdapatnya penurunan HOMA-IR rata-rata dari 2,8 $( \pm 0.5)$ menjadi $1,4( \pm 0,4)$ setelah intervensi dengan metformin 3 gram/hari dan fenofibrat selama 12 minggu yang signifikan dengan $p<0.001$. Dari beberapa studi yang ada, tampaknya dosis dari metformin bervariasi bergantung individual. ${ }^{11,12}$
Studi oleh Kadhim dkk. ${ }^{11}$ di Iraq mencoba membandingkan efek metformin dengan HOMAIR menggunakan beberapa dosis yang berbeda. Grup pertama (20 pasien) diberikan dosis 500 mg 2x/hari, grup kedua (20 pasien) diberikan dosis $500 \mathrm{mg} 3 \mathrm{x} /$ hari, dan grup ketiga (20 pasien) diberikan dosis $1.000 \mathrm{mg} 2 \mathrm{x} /$ hari selama 3 bulan. Dari studi ini tampak bahwa penurunan paling signifikan HOMA-IR didapatkan pada grup ketiga dengan dosis yang paling tinggi ( $2.000 \mathrm{mg} /$ hari) meskipun pada ketiga grup ini didapatkan penurunan HOMA-IR rata-rata yang signifikan secara statistik dibanding dengan nilai dasar $(5,5)$, pada masing-masing grup pertama, kedua, dan ketiga masing-masing $4,4( \pm 0,08), 4,3$ $( \pm 0,12), 4,2( \pm 0,11)$ dengan $p<0,001$.

Pada penelitian ini didapatkan penurunan HOMA-IR rata-rata subjek pada kelompok puguntano sebelum pemberian intevensi adalah 3,79 dan sesudah intervensi turun menjadi 2,08 dan hasil analisis dengan uji Wilcoxon ditemukan perbedaan HOMA-IR rata-rata yang signifikan antara sebelum dan juga sesudah pemberian puguntano dengan penurunan rata-rata 1,71 ( \pm $2,09)(p=0,034)$.

Perbandingan delta penurunan kadar HOMAIR antara dua kelompok studi, tampak bahwa penurunan HOMA-IR kelompok puguntano sedikit lebih besar dibanding dengan kelompok metformin yaitu dengan delta penurunan adalah 1,71 dan 0,8 masing-masing. Berdasar atas uji Mann-Whitney perbedaan delta penurunan kadar HOMA-IR rata-rata diantara grup puguntano dan metformin menunjukkan tidak terdapat perbedaan delta rata-rata yang signifikan $(p=0,402)$. Sebagai tambahan studi ini juga memperlihatkan bahwa Hba1c pada kedua grup, puguntano dan metformin sebesar $1.53 \%$ $( \pm 1,99)(\mathrm{p}<0,022)$ dan $1,48 \%( \pm 2,0)(\mathrm{p}<0,012)$ masing-masing, Analisis Mann-Whitney juga didapatkan perbedaan yang tidak signifikan antara kedua grup $(\mathrm{p}=0,686)$.

Dapat disimpulkan bahwa efek puguntano dalam mengontrol gula darah terutama peranan memperbaiki sensitivitas insulin tidak jauh berbeda dengan metformin yang telah menjadi obat standar pengobatan lini pertama diabetes melitus tipe 2 .

Penelitian ini juga mempunyai keterbatasan di antaranya sampel yang sedikit sehingga kemungkinan belum dapat menunjukkan hasil yang sebenarnya, juga aktivitas dan menu makan pasien yang menjadi sampel tidak dapat diseragamkan sehingga dapat mengganggu hasil pengukuran yang dilakukan. 


\section{Daftar Pustaka}

1. Okita K, Iwahashi H, Kozawa J, Okauchi Y, Funahashi T, Imagawa A, dkk. Homeostasis model assessment of insulin resistance for evaluating insulin sensitivity in patients with type 2 diabetes on insulin therapy. Endocr J. 2013;60(3):283-90.

2. Taylor R. Insulin Resistance and Type 2 Diabetes. Diabetes. 2012;61(4):776-9.

3. Harfina F, Bahri S, Saragih A. Pengaruh serbuk daun puguntano (Curanga fel-terrae Merr) pada pasien diabetes melitus. J Pharmaceutics Pharmacol. 2012;1(2):1128.

4. Sitorus P, Harahap U, Pandapotan M, Barus T. Isolation of $\beta$-sitosterol from $n$-Hexane extract of picria fel-terrae lour leave and study of its antidiabetic effect in alloxan induced diabetic mice. Int J PharmTech Res. 2014;6(1):137-41.

5. Juwita NA. Pengujian efek antiinflamasi ekstrak etanol daun pugun tano (Curanga felterrae Merr) terhadap mencit putih [skripsi]. Medan: Fakultas Farmasi USU; 2009.

6. Saha PK, Reddy VT, Konopleva M, Andreeff M, Chan L. The Triterpenoid 2-Cyano-3,12dioxooleana-1,9-dien-28-oic-acid methyl ester has potent anti-diabetic effects in dietinduced diabetic mice and Lepr ${ }^{\mathrm{db} / \mathrm{db}}$ mice. J Biol Chem. 2010;285(52):40581-92.
7. Rojas LBA, Gomes MB. Metformin: an old but still the best treatment for type 2 diabetes. Diabetol Metab Syndr. 2013;5(1):6.

8. Iliadis F, Kadoglou NP, Hatzitolios A, Karamouzis M, Alevizos M, Karamitsos D. Metabolic effects of rosiglitazone and metformin in Greek patients with recently diagnosed type 2 diabetes. In Vivo. 2007; 21(6):1107-14.

9. Ma J, Liu LY, Wu PH, Liao Y, Tao T, Liu W. Comparison of metformin and repaglinide monotherapy in the Treatment of new onset type 2 diabetes melitus in china. J Diabetes Res. 2014;2014:294017.

10. Krysiak R, Gdula-Dymek A, Okopien B. Effect of metformin on selected parameters of hemostasis in fenofibrate-treated patients with impaired glucose tolerance. Pharmacol Rep. 2013;65(1):208-13.

11. Kadhim KA, Ismael DK, Khalaf BH, Husseiun KL, Zalzala MH, Hussain SA. Dose-dependent relationship between serum metformin levels and glycemic control, insulin resistance and leptin levels in females newly diagnosed with type 2 diabetes melitus. J Diabetes melitus. 2012;2(2):179-85.

12. Frid A, Sterner GN, Londahl M, Wiklander C, Cato A, Vinge E, dkk. Novel assay of metformin levels in patients with type 2 diabetes and varying levels of renal function. Diabetes Care. 2010;33(6):1291-3. 